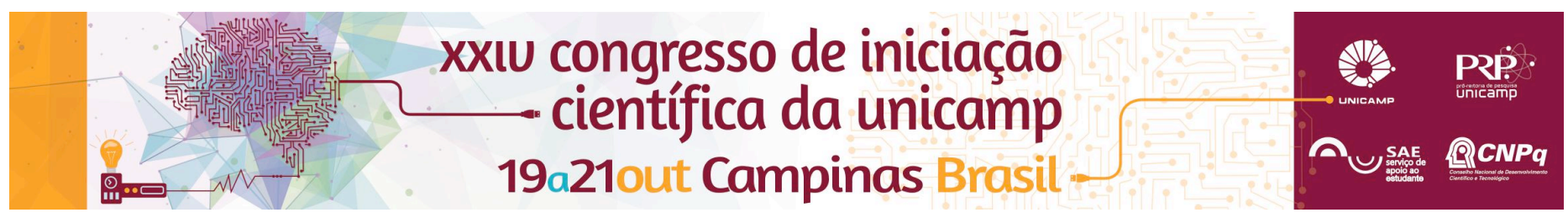

\title{
Aspectos Estilísticos na Obra de Avishai Cohen: Análise e Adaptações para Violão Solo
}

\section{Guilherme C. L. V. Alves*, Leandro Barsalini.}

\section{Resumo}

Estudo de três composições contidas no disco Gently Disturbed, do contrabaixista israelense Avishai Cohen. Com o intuito de compreender o estilo composicional do músico e, em um segundo momento, dialogar com o universo do violão, com a realização das transcrições, análises rítmicas e harmônicas, transposições e recriação das peças para violão solo.

\section{Palavras-chave:}

Transcrição, Violão, Avishai Cohen.

\section{Introdução}

O pesquisa teve como objeto de estudo três peças contidas no disco Gently Disturbed, do compositor israelense Avishai Cohen. As composições Seattle e Lo Baiom Velo Balyla representam o grupo em que o músico trabalha a fórmula de compasso $3 / 4 \mathrm{com}$ uma célula rítmica específica como base, e, em The Ever Evolving Etude, o trabalho rítmico e de sobreposição contrapontística de camadas melódicas, em $6 / 4$, sobre a harmonia i / iv / V. O método de pesquisa previu a comparação do áudio original com as partituras do songbook Gently Disturbed, realizando as alterações e complementações necessárias e transcrevendo para o programa Sibelius, análises rítmicas e harmônicas, e em seguida, a "recriação" para violão solo, realizando os devidos ajustes de tonalidade e abertura de acordes, já que as peças são originais para piano.

\section{Resultados e Discussão}

Como resultado final, foram realizadas as "recriações" das obras para violão solo, com as partituras completas discriminando digitações, pestanas, cordas usadas $e$ harmonias, seguindo o método de transcrição de, por exemplo, Paulo Bellinatti em seu livro Guitar Works of Garoto. O método de comparação entre as partituras contidas no Songbook Gently Disturbed e os áudios originais gerou partituras mais fiéis e completas, permitindo melhor compreensão e análises.

A transposição entre instrumentos, no caso piano para violão, também enriqueceu as possibilidades técnicas do instrumento, pois buscou-se, na medida do possível, e respeitando seu idiomatismo, assemelhar-se aos timbres providos do piano, principalmente a sustentação das notas e brilho.

O compositor explora a célula em $3 / 4$ abaixo em quatro músicas do disco, e possui uma relação contrapontística entre baixo e melodia, estudada nas músicas Seattle e Lo Baiom Velo Balyla.

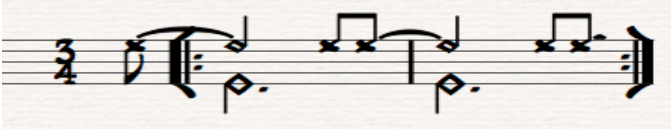

Figura 1. Inserir aqui o título da figura.

Em The Ever Evolving Etude, a tônica da pesquisa foi em cima da sobreposição de camadas melódicas construindo alguns grooves em cima da progressão Cm /
Fm / G, na fórmula de compasso 6/4, que possibilita uma relação de dois tempos por acorde. Esse tipo de tipo de técnica é também bastante empregado pelo compositor ao longo de sua obra.

\section{Conclusões}

A pesquisa possibitou um contato maior $e$ aprofundamento no estilo composicional do músico, onde a rítmica é trabalhada e desenvolvida com maior ênfase, junto a harmonia tradicional advinda da música erudita, e as fórmulas de compasso não usuais ampliam as possibilidades do sistema tonal tradicional. As perspectivas de continuidade do projeto se dão nesse âmbito, da busca pelo enriquecimento de material e possibilidades para o sistema tonal, empregando-o, por exemplo, em fórmulas de compasso menos usuais na música popular, promovendo uma nova relação do ritmo harmônico, e "oxigenando" a teoria da tonalidade já desenvolvida. $O$ trabalho de transposições entre instrumentos, aumentando consequentemente a publicação de material sobre o compositor - que ainda está em fase de produção de sua obra, - também é um desdobramento possível a pesquisa, enriquecendo o repertório para violão solo.

A pesquisa também se desdobrou em vídeos feito pelo pesquisador executando as recriações ao violão https://www.youtube.com/watch?v=ZkvQAqhw2AE

https://www.youtube.com/watch?v=g-

r42C4xuaY\&feature=youtu.be

\section{Agradecimentos}

Agradeço meu orientador Leandro Barsalini e ao ao PIBIC/SAE pela oportunidade e por viabilizar a realização da pesquisa.

COHEN, Avishai. Avishai Cohen: Songbook Vol. 2 - Gently Disturbed,

Music for Trio. Gadu Music/BMI

BERRY, Wallace T. Structural Functions in Music. Courier Dover Publications, 1976.

SCHOENBERG, Arnold. Harmonia. Trad. Marden Maluf. São Paulo: Editora UNESP, 2001

BELLINATTI, Paulo. The Guitar Works of Garoto, voll e 2 -transcribed, arranged \& edited from his recordings \& manuscripts by Paulo Bellinatti.

GUEST, Ian. Arranjo - Método Prático Vol.1. Irmãos Vitale, 1996.

JÚNIOR, Fanuel Maciel de Lima. A Elaboração de Arranjos de Canções Populares para Violão Solo. UNICAMP, 2003. 